\title{
Timing is everything: the regulation of type III secretion
}

\author{
Janet E. Deane $\cdot$ Patrizia Abrusci $\cdot$ Steven Johnson • \\ Susan M. Lea
}

Received: 18 September 2009/Revised: 23 November 2009/ Accepted: 8 December 2009/Published online: 31 December 2009

(C) The Author(s) 2009. This article is published with open access at Springerlink.com

\begin{abstract}
Type Three Secretion Systems (T3SSs) are essential virulence determinants of many Gram-negative bacteria. The T3SS is an injection device that can transfer bacterial virulence proteins directly into host cells. The apparatus is made up of a basal body that spans both bacterial membranes and an extracellular needle that possesses a channel that is thought to act as a conduit for protein secretion. Contact with a host-cell membrane triggers the insertion of a pore into the target membrane, and effectors are translocated through this pore into the host cell. To assemble a functional T3SS, specific substrates must be targeted to the apparatus in the correct order. Recently, there have been many developments in our structural and functional understanding of the proteins involved in the regulation of secretion. Here we review the current understanding of protein components of the system thought to be involved in switching between different stages of secretion.
\end{abstract}

Keywords Type III Secretion - Regulation · Gram-negative bacteria $\cdot$ Virulence

J. E. Deane · P. Abrusci · S. Johnson · S. M. Lea

Sir William Dunn School of Pathology,

University of Oxford, South Parks Rd,

Oxford OX1 3RE, UK

\section{S. M. Lea}

e-mail: susan.lea@path.ox.ac.uk

Present Address:

J. E. Deane $(\square)$

Cambridge Institute for Medical Research,

Wellcome Trust/MRC Building,

Addenbrooke's Hospital, Hills Road,

Cambridge CB2 0XY, UK

e-mail: jed55@cam.ac.uk

\section{Introduction}

Many Gram-negative bacterial pathogens use Type Three Secretion Systems (T3SSs) to inject bacterial virulence proteins directly into eukaryotic host target cells. T3SSs are complex macromolecular machines that consist of the structural components of the apparatus itself, secreted proteins (including pore-forming translocators and effectors), chaperones and cytoplasmic regulators. The apparatus is made up of a basal body that spans both bacterial membranes and an extracellular needle that protrudes from the bacterial surface. The basal body possesses rotational symmetry and is made up of several rings of integral membrane and periplasmic proteins (reviewed in $[1,2])$. During morphogenesis, the components of the transmembrane rings are handled by the Sec machinery while subsequent components are sequentially exported by the T3S apparatus itself $[3,4]$. The needle projects from the basal body and is assembled by the polymerization of a single, small needle subunit (reviewed in [5, 6]). Both the basal body and needle are hollow, containing a channel that is thought to act as a conduit for protein secretion [7, 8]. The needle terminates in a tip structure made of several copies of the tip protein (reviewed in [5, 6, 9]). Upon contact with a host-cell membrane, the T3SS exports two distinct categories of proteins: the translocators that form a pore in the target membrane and the effectors that traffic through this pore into the host cell.

In order to build a functional T3SS, there are distinct stages during assembly that have specific requirements regarding the substrates to be exported and the timing of the switch to the next stage. These stages are briefly outlined below and illustrated in Fig. 1. Early substrates such as the proteins that make up the rod (the periplasmic portion of the needle that lies within the basal body) and 


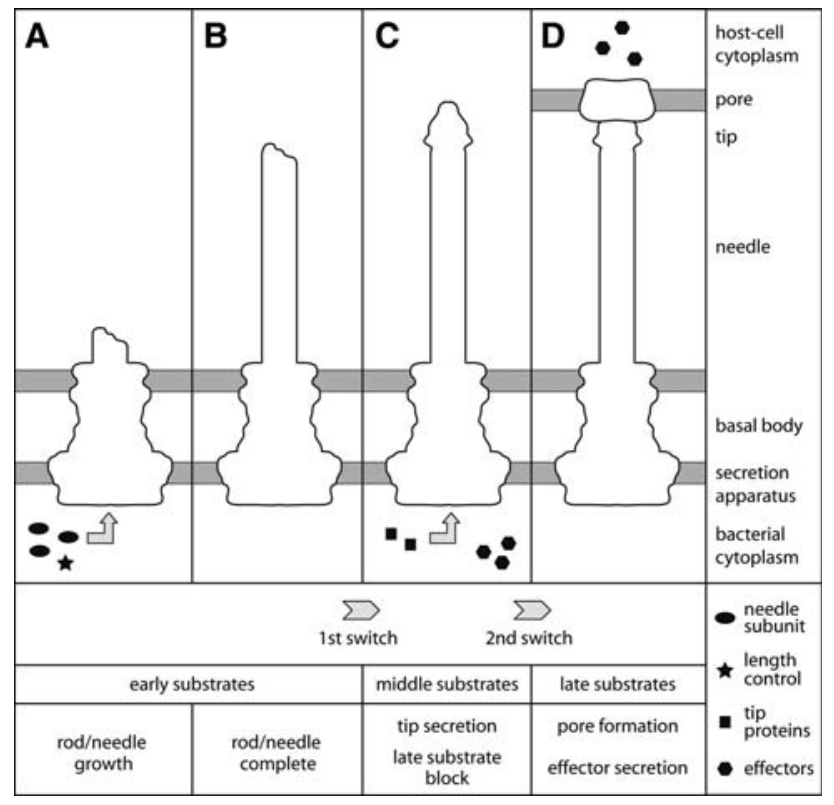

Fig. 1 Schematic diagram illustrating different secretion states of pathogenic Type Three Secretion Systems. a Following assembly of the basal body (black outline) into the inner and outer bacterial membranes (grey), early substrates including the needle subunit (black oval) and the needle-length control protein (black star) are targeted to the apparatus for secretion. b The secreted needle subunits assemble to form a hollow extracellular needle. Upon completion of the needle, the secretion apparatus undergoes the first substrate specificity switch to secrete the tip proteins. c Tip proteins (black squares) are secreted and assemble at the tip of the needle, and further secretion is blocked until host-cell contact. d Host-cell contact triggers the second switch at which point the pore-forming translocator proteins are inserted into the host-cell membrane, and effector proteins (black hexagons) are targeted to the host cell

needle must be targeted to the secretion apparatus after the membrane rings are formed (Fig. 1a) [3]. This stage must be monitored as it is known that the length of the needle is well controlled [10-12]. Thus, the substrate specificity of the apparatus must be switched at the appropriate point to arrest needle growth (Fig. 1b) [13]. The trigger for this switch involves a component of the inner membrane and an early substrate of the export apparatus, a cytoplasmic protein known as the length-control protein [14, 15]. Following completion of the needle structure, the tip proteins are exported, and secretion must be blocked until contact with a host-cell membrane (Fig. 1c) [16]. This block is mediated in part by a cytoplasmic protein that is thought to act as a gatekeeper and that may be able to respond to specific signals following host-cell contact [17-20]. Upon contact, translocators must be secreted and inserted into the host cell membrane to form a pore prior to secretion of late substrates, the effectors (Fig. 1d) [21, 22]. In this way, effectors will be exported directly into host cells rather than into the extracellular milieu.

Clearly, pathogens require several mechanisms to ensure hierarchical and temporal control over the secretion of
T3SS components. Regulation of secretion is controlled at several levels: transcriptional, post-transcriptional, translational as well as via the conformational switching and secretion of T3SS components (reviewed in $[23,24]$ ). In this review, we will address the most recent work relating to the protein components of the system thought to be involved in the switching between different stages of assembly and secretion. Component names from representative families are provided in Table 1. Although there are significant homologies between pathogenic T3SS and flagellar secretion, especially in the early stages of assembly, we will not include a detailed discussion of flagella components in this review as this has been covered by other recent reviews [25-27].

\section{The secretion apparatus: components and targeting}

Reconstructions of the basal body reveal the presence of a socket structure within the inner membrane ring [28, 29]. This structure is visible from the cytoplasmic face of the basal body and extends into the hollow chamber of the T3SS basal body. The socket is thought to act as an anchor for the inner rod that traverses the length of the basal body and connects to the extracellular needle. Although the proteins that make up the socket structure have not been identified, it is likely to be formed by at least some of the domains of the five well-conserved inner membrane proteins that are associated with the basal body. In Shigella these are: Spa9, Spa29, Spa24, Spa40 and MxiA (Table 1). The roles these inner membrane proteins may play in export are not well understood. However, two of these components (Spa40 and MxiA) possess cytoplasmic domains [30-32] that are likely to be accessible to cytoplasmic proteins such as the secretion substrates, their chaperone-complexes and cytoplasmic regulators.

As protein production and secretion are not always coupled, some T3SS proteins must be stored in the bacterial cytoplasm in a secretion-competent state, but blocked from interacting prematurely with partner proteins or the apparatus itself. Specialised chaperones play this role by reversibly binding one or several partner proteins. Several different classes of chaperones can be distinguished based on structural and functional analysis as reviewed in [33-36].

Recognition and targeting of proteins to the T3S apparatus requires that secreted proteins possess a secretion signal. Several studies have identified a signal in the $\mathrm{N}$-terminus of effector proteins either encoded in the mRNA [37, 38] or the peptide sequence [39-42]. Recently, several groups have used machine learning techniques to identify cryptic secretion signals within the protein sequence of the $\mathrm{N}$-terminus of T3SS effector proteins [43-45]. Although these studies indicate that most secreted 
Table 1 Equivalences between representative families for components mentioned in the text (adapted from [87])

\begin{tabular}{|c|c|c|c|c|}
\hline & Shigella flexneri & Escherichia coli LEE & Yersinia sp. & $\overline{\text { Salmonella } \text { sp. SPI-1 }}$ \\
\hline \multicolumn{5}{|l|}{ Early substrates } \\
\hline Needle subunit & $\mathrm{MxiH}$ & EscF & YscF & PrgI \\
\hline Rod subunit & MxiI & EscI & YscI & $\operatorname{PrgJ}$ \\
\hline Length-control & Spa32 & Orf $16^{\mathrm{a}}$ & YscP & InvJ \\
\hline \multicolumn{5}{|l|}{ Middle substrates } \\
\hline Tip & IpaD & $\operatorname{EspA}^{\mathrm{b}}$ & LcrV & SipD \\
\hline Pore & $\mathrm{IpaB} / \mathrm{C}$ & EspD/B & YopB/D & $\mathrm{SipB} / \mathrm{C}$ \\
\hline \multicolumn{5}{|c|}{ Secretion apparatus components } \\
\hline Inner-membrane & Spa9 & EscS & YscS & SpaQ \\
\hline Inner-membrane & Spa29 & EscT & YscT & SpaR \\
\hline Inner-membrane & $\mathrm{Spa} 24$ & EscR & YscR & SpaP \\
\hline Inner-membrane & MxiA & $\mathrm{EscV}$ & YscV & InvA \\
\hline Switch & Spa40 & EscU & YscU & SpaS \\
\hline ATPase & Spa47 & $\mathrm{EscN}$ & $\mathrm{YscN}$ & InvC \\
\hline ATPase-associated & MxiN & EscL & YscL & OrgB \\
\hline ATPase-associated & MxiK & Orf4 & YscK & OrgA \\
\hline ATPase-associated & Spa33 & EscQ & YscQ & $\mathrm{SpaO}$ \\
\hline Regulator/gatekeeper & MxiC & SepL & YopN/TyeA & InvE \\
\hline
\end{tabular}

${ }^{a}$ Based on its position within the type III secretion gene cluster and its predicted secondary structure, Pallen et al. identify Orf16 as a candidate for the needle-length control protein [87]

b The Escherichia coli extension to the basal body is very different from that of other T3SS as it possesses an additional filament structure beyond the needle. Thus, the polymerization of EspA is quite different from that of the other tip proteins (reviewed in [5])

substrates possess a protein-encoded secretion signal, they do not preclude the role of mRNA as some effectors are surprisingly tolerant to frameshift mutations [44]. The secretion signals of early substrates appear to be different from that of the effectors. In Pseudomonas syringae, $\mathrm{N}$-terminal truncations of the needle-length control protein, HrpP, were still translocated, suggesting this substrate possesses an atypical secretion signal [46]. In Yersinia, it has been shown that the needle-length control protein possesses two independent secretion signals, only one of which is at the N-terminus [47]. In addition, studies of the Yersinia tip protein reveal that an N-terminal His tag does not block secretion and that the $\mathrm{C}$-terminus is also required for export, suggesting that the signal sequences differ between early and late substrates. However, there is currently very little data available on the specific targeting of early substrates to the T3S apparatus.

\section{The first switch: needle length control via substrate specificity switching}

The substrate specificity switch from early substrates (needle and rod subunits) to later substrates must only occur once the needle has reached its full length. This is important since the length of the needle must match specific structures at the bacterial and host-cell surfaces [48, 49]. Needle length varies between species, but is well controlled within species: $\sim 50 \mathrm{~nm}$ in Shigella, $\sim 60 \mathrm{~nm}$ in Yersinia enterocolitica and $\sim 55 \mathrm{~nm}$ in SPI-1 of Salmonella [10-12, 21, 50]. At its simplest, length control involves two steps: the measurement of needle length and the switch of substrate specificity, i.e., halting the secretion of needle subunits. The needle-length control proteins are located in the same region of their respective genomes, but they possess very little sequence identity, and large regions are predicted to be highly unstructured. Knockout mutations of Spa32 in Shigella, InvJ in Salmonella or YscP in Yersinia lead to abnormally long needles and defects in effector secretion [10-13, 15, 51-54].

Several recent reviews have discussed in detail the different models for needle-length control in T3SS and flagella [55-58] as well as the homology of these control mechanisms to those used by bacteriophage-tail and flagella-hook length control [55]. For this reason, we will restrict this discussion to the data and models relevant to understanding the most recent work done in this field.

Needle length: the ruler/tape-measure model

In Yersinia, insertions and deletions were engineered into the $y s c P$ sequence and the length of needles measured [10]. 
This work identified a linear correlation between the number of residues of $\mathrm{YscP}$ and the mean needle length, suggesting that the extended protein might act as a molecular ruler. Mutation of the secretion signals of $\mathrm{YscP}$ reduces or abolishes its secretion, and length control is dramatically impaired [47]. This result suggests that the export of YscP is coupled to its measuring activity, leading to the proposal that $\mathrm{YscP}$ may measure needle length directly. This model proposes that YscP would function as an extended polypeptide anchored to the tip of the growing needle and the base of the needle complex. Its full extension would signal that the needle has reached the appropriate length. A recent paper by Wagner et al. has shown that in Yersinia, the needle length changed in inverse function of the helical content, indicating that not only the number of residues but also their structure controls length [59]. These data support the ruler model and indicate that the functional ruler in this system possesses some helical structure. In some species the needle-length control protein is much shorter than in Yersinia, for example, Spa32 from Shigella possesses only 292 residues compared with 515 residues for YscP. As the Shigella needle is only $\sim 15 \%$ shorter than in Yersinia, this suggests that Spa32 would possess almost no helical content while measuring the needle length. Future studies altering the amount of helical content in different members of this family will help establish the importance of secondary structure in determining needle length across species.

This model for needle-length control implies that the length-control protein is either present in the needle channel while needle subunits are being secreted or that it can be secreted without triggering the substrate switch. This latter model was originally proposed in the flagella field and was named the "infrequent export" model [60]. In this model, the needle length-control protein is periodically secreted during needle assembly to "check" whether the needle has reached full length. This would require that the mechanism by which it signals completion of the needle must not be prematurely triggered (see the substrate switch section below). The possible mechanisms by which this may work remain unclear. Alternatively, if the lengthcontrol protein remains in the needle channel, there must be sufficient room to fit both the ruler protein and the needle subunits being secreted. Several different methods have been used to estimate the diameter of the bore of the needle. The electron microscopy reconstruction of the Shigella needle resulted in a bore of $2.5 \mathrm{~nm}$ [61]. The modelling of the needle assembly within this reconstruction using the X-ray structure of the needle subunit from Shigella gave a bore size of $1.8 \mathrm{~nm}$ [62]. This difference is likely due to the uncertainties inherent in each method, for example, the relatively low resolution of the reconstruction and the ambiguity in positioning of the helices lining the needle channel $[61,62]$. Since a folded $\alpha$-helix (including side chains) has a diameter of $\sim 1.2 \mathrm{~nm}$, the question of whether one or two folded helices can simultaneously fit in the needle channel remains uncertain. If the ruler remains in the needle channel during assembly, the narrower bore size would require the complete unfolding of either the ruler or the needle subunit protein. If the ruler protein is unfolded, then the secondary structure content becomes irrelevant in the measurement, and so the results of Wagner et al. require that the needle subunit be completely unfolded.

Recent work in Shigella has shown that large deletions within spa32 do not produce shorter needles than those generated by variations with minimal deletions [14]. Furthermore, Spa32 variants lacking internal residues 37-94 or 130-159 retained full Spa32 function indicating that, in Shigella, control of needle length is not via a YscP-like molecular ruler mechanism. Botteaux et al. also showed that Spa32 and InvJ or YscP are functionally interchangeable (including needle-length control and translocator secretion) despite very different protein sizes. In contrast, insertion of just the YscP ruler domain into Spa32 produced longer needles, supporting the role of YscP as a molecular ruler [10, 14]. As discussed previously this may be subtly affected by the proportion of helical content in these proteins, but does suggest that the measuring function may be subtly different between species and that the current ruler/tape-measure models may be oversimplified.

Substrate specificity switching: the Spa32-like proteins

Despite the low sequence homology of the needle-length control proteins, a small domain near the C-terminus of these proteins was identified by hydrophobic cluster analysis and named the type III secretion substrate specificity switch (T3S4) domain [63]. This domain is predicted to possess a globular structure, an $\alpha \beta$-fold and a Pro$\mathrm{x}$-Leu-Gly signature. In Yersinia, the over-expression of this domain in strains lacking $y s c P$ restores secretion of effectors, but needle length remains variable, suggesting the T3S4 domain plays a role in the substrate switch. Together with the results discussed above, this suggests that this family of proteins may be bifunctional: they determine needle length and trigger the substrate switch.

Substrate specificity switching: the Spa40-like proteins

The switch of substrate specificity is also controlled by one of the inner membrane components of the system, the highly conserved Spa40 family [55, 58, 64, 65]. These proteins possess a cytoplasmic domain that has been shown to undergo an autocatalytic cleavage event to produce a 
small C-terminal domain that remains tightly associated with the membrane-bound $\mathrm{N}$-terminal fragment. Cleavage occurs between the Asn and Pro within the highly conserved Asn-Pro-Thr-His (NPTH) sequence within the cytoplasmic domain. Mutants of the $\mathrm{N}$ and $\mathrm{P}$ prevent cleavage and interfere with the substrate switch. Noncleavable mutants in Salmonella SpaS and E. coli EPEC EscU block secretion of translocators and filament components [64]. Similarly, mutation of the $\mathrm{N}$ or $\mathrm{P}$ to alanine (N263A or P264A) in the Yersinia homologue YscU results in bacteria that do not export the tip protein or translocators (LcrV, YopB and YopD) [65]. These non-cleaving mutants do form needles, although longer and less controlled than the wild type, and are capable of secreting late effectors [65]. In the YscU N263A mutant strain, export of the tip protein can be restored if a hybrid protein is constructed that possesses at its $\mathrm{N}$-terminus the signal sequence from an effector protein (residues 1-15 of YopE) [65]. This implies that the tip/translocators have a specific type of export signal and a status distinct from the late effectors regarding export. This led to the proposal that $\mathrm{YscU}$ cleavage is required to adopt the conformation allowing recognition of the translocators.

In the last year several structures have been determined for the cytoplasmic domain of proteins belonging to this family: Esc $\mathrm{U}_{\mathrm{C}}$ of E. coli, $\mathrm{SpaS}_{\mathrm{C}}$ of Salmonella, Spa40 ${ }_{\mathrm{C}}$ of Shigella and $\mathrm{YscU}_{\mathrm{C}}$ of Yersinia [64, 66-68] (Fig. 2). These structures revealed that the NPTH sequence lies on a surface-exposed loop and is cleaved in the absence of any other factors (Fig. 2, main panel). Structures of cleaved and uncleavable mutants of these proteins reveal that there is a distinct conformation for this loop in each state and that the cleaved loop is stabilised by surrounding residues (Fig. 2, bottom inset). Analysis of the uncleavable mutants suggests that the protein fold presents the loop in a conformation that is primed for the cleavage event to occur. It has therefore been proposed that cleavage occurs immediately upon folding and that the switching event is a consequence of partner proteins interacting with the cleaved protein. In artificial systems where the cleavage event is blocked by mutation, the surface properties of the protein are altered and thus may not present the necessary structure for substrate switching rather than the structure of the uncleaved form playing an active role in inhibiting the switch. If, as has been proposed in the flagella field, cleavage of this loop acts as a trigger for substrate switching, then the timing of this cleavage event becomes critical, and these proteins must be maintained in an uncleavable state until the needle is completed. Such a state could be attained by the specific chemistry of the protein fold itself, or by external factors such as $\mathrm{pH}$ or inhibitory proteins. It should be noted that in wild-type $Y$. enterocolitica with YscU expressed at natural levels, the cleavage
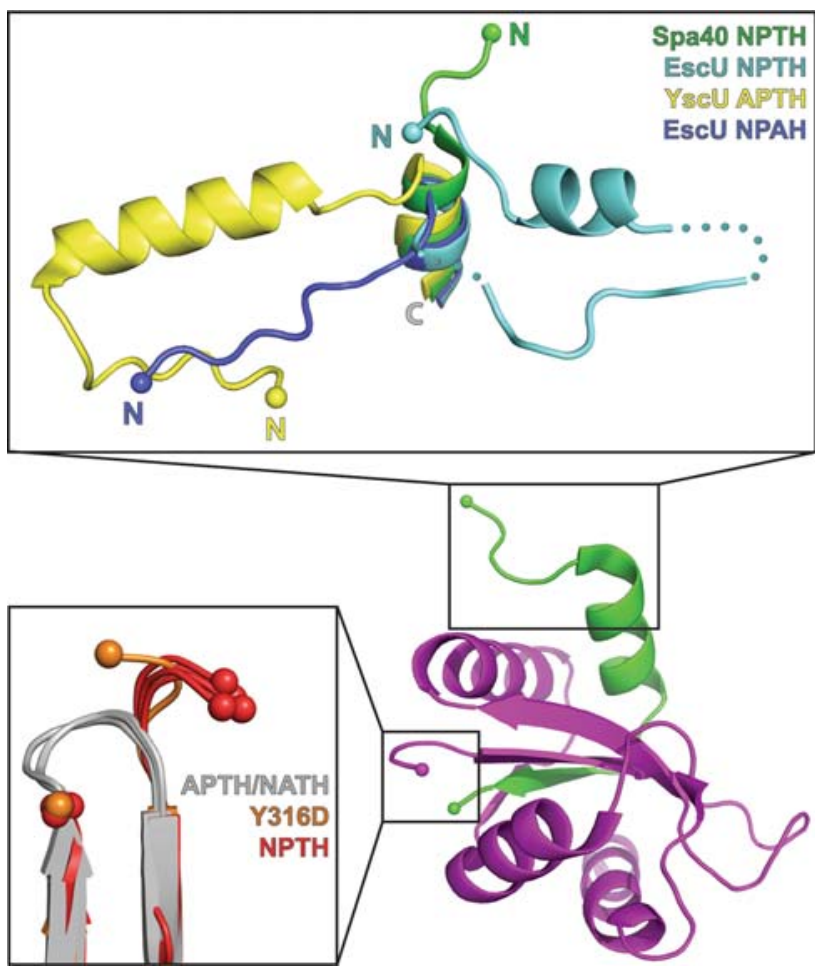

Fig. 2 Structures of the cytoplasmic domain of the substrate specificity switch protein. Main panel: Ribbon diagram of Shigella flexneri $\mathrm{Spa}_{4} 0_{\mathrm{C}}$ illustrating the $\mathrm{N}-($ green $)$ and $\mathrm{C}-($ magenta) terminal regions of this domain (PDB: 2VT1). Left panel: Overlay of the NPTH-loop region from cleaved and non-cleavable mutants of EscU, SpaS, Spa40 and YscU (PDB: 3BZL, 3BZP, 3BZY, 3C01, 2VT1, 2V5G, 2JLJ, 2JLI). Top panel: Views of the N-terminal regions of $\mathrm{EscU}, \mathrm{Spa} 40$ and $\mathrm{YscU}$ overlaid via the C-terminal region to illustrate the lack of defined structure at the N-terminus (PDB: 3BZL, 3BZV, 2VT1, 2V5G)

at the NPTH site was not complete, i.e., full length uncleaved protein was detected in purified membranes [65]. This is therefore an area that requires further investigation.

The structures also revealed that the $\mathrm{N}$-terminal portion of the cytoplasmic domain is able to adopt very different conformations (Fig. 2, top inset). This flexibility may be due to different crystallisation conditions or may be the result of separating this domain from the membrane-bound portion of the protein. It is also possible that this region is genuinely flexible and that the position of this domain within the secretion apparatus may play a role in regulation. As shown previously for flagella, deletions or point mutations in this region of EscU abolish secretion of both translocators and effectors [64, 69]. This suggests a distinct role for this region in the export capability of the apparatus rather than its substrate specificity. Further experiments are required to address this question, including a structure of the intact, full-length protein including the N-terminal integral membrane region. 
Substrate specificity switching: working together

In addition to lack of translocator export, the $\mathrm{YscU}$ N263A mutant exported reduced amounts of $\mathrm{YscP}$ and made longer needles [65]. Overexpression of yscP in the N263A strain resulted in increased export of YscP, resulting in needles of normal length, but did not restore translocator secretion. Therefore, failure in needle length control of the N263A mutant was due to the failure of YscP export rather than the failure to switch substrate specificity. Furthermore, the recovery of needle-length control indicates that the N263A mutation does not affect the capacity of the T3S export apparatus to switch off the export of needle subunits. Since the uncleavable variant of $\mathrm{YscU}$ can give rise to different needle lengths depending on the amount of YscP exported, this supports the hypothesis that the cleavage event itself is not the trigger.

Much work has been done in the flagella field looking at the interplay between the hook-length control protein, FliK, and the substrate switching protein, FlhB (reviewed in $[57,58])$. Specific mutations within the cytoplasmic domain of FlhB were identified that rescue the $f i K$ null mutant [70, 71]. Equivalent mutations were made in Yersinia $\mathrm{YscU}$ and were shown to restore effector secretion (i.e. are capable of switching) in $y s c P$ null mutants [15]. These data suggest that $\mathrm{YscU}$ and $\mathrm{YscP}$ work together to control both needle length and switch the substrate specificity of the secretion apparatus. Recently, Botteaux et al. have identified a direct interaction between the cytoplasmic domain of Spa40 and a short C-terminal region within the predicted T3S4 domain of Spa32 [14]. Removal of these residues from Spa32 resulted in a nonfunctional protein suggesting that the interaction with Spa40 is crucial for the switch from early to later substrates.

Recent work from Riordan et al. has identified interactions between $\mathrm{YscU}$ and ATPase-regulator complexes. When purified from the cytoplasm of Yersinia, cleaved $\mathrm{YscU}_{\mathrm{C}}$ bound to $\mathrm{YscL} / \mathrm{K} / \mathrm{Q}$ but lacked interaction with $\mathrm{YscN}$ or $\mathrm{YscP}$ or LcrV [72]. It was also shown that overexpression of any ysc $U$ allele (including wild-type) abolished type III secretion, suggesting that $\mathrm{YscU}$ may bind and sequester an essential component of the apparatus [72]. Furthermore, a GST-fusion protein of the cytoplasmic domain of $\mathrm{YscU}$ was found in the cytoplasm not associated with the T3S apparatus, but was still able to block secretion [73]. These results suggest a role for $\mathrm{YscU}$ in the recruitment of ATPase complexes to the T3S apparatus in order to initiate secretion. Similarly, impassable GST fusions of YscP have been shown to block secretion and co-purify with ATPase complexes [73].
Needle length: the rod assembly model

There is little dispute that the Spa32 family of proteins is responsible for needle-length control and substrate switching. However, as briefly mentioned earlier, there is some disagreement in the literature about its role as a ruler/ tape measure. Alternative models for needle-length control have been proposed in both pathogenic and flagella T3SS (reviewed in [55-58]). One model that we discuss here involves a component known as the rod protein that is thought to be the periplasmic portion of the needle. In Salmonella, it has been shown that the needle-length protein, InvJ, is required for formation of the inner rod structure, and reconstruction of a $\Delta i n v J$ needle complex revealed significant structural differences within the base [74]. Although, InvJ is not detected as an integral component of the base $[11,75]$, the $\Delta i n v J$ reconstruction supports a role for InvJ in stabilisation of the socket and inner rod structures. The model proposed by Marlovits et al. suggests that completion of the inner rod anchors the needle to the base and triggers a conformational change in the base that switches substrate specificity.

Marlovits et al. also showed that altering the stoichiometry of the inner rod and needle proteins has a profound impact on the length of the needle substructure [74]. Recent work has shown that in Yersinia the rod protein, YscI, plays a critical role in substrate specificity switching [76]. Wood et al. suggest that YscP and YscU exert their effects on substrate export by controlling the secretion of YscI [76]. Together these observations support a role for the rod protein in needle-length determination.

The abundance of data available relating to needle length control in several species and in pathogenic and non-pathogenic T3SS has allowed the proposal of many different mechanisms for length control. It seems likely that the fundamental mechanism of needle-length control will be conserved across species, but at this stage these models cannot yet be reconciled and in some cases appear to be incompatible.

\section{The second switch: assembly of the tip and late substrate block}

After completion of the needle structure, the tip complex is assembled at the end of the needle, and the secretion of effector proteins must be blocked. In Yersinia, a tip complex has been visualised that is assembled at the tip of the needle [77]. This complex is made up of several copies of the protein LcrV and is present even in the absence of effector secretion [77], suggesting that the secretion of these two classes of substrates, tip protein and effectors, is differently controlled. 
In Shigella, IpaD has been identified at the tip of the needle $[78,79]$, has been shown to interact directly with the needle subunit, $\mathrm{MxiH}$, in vitro [80], and is required for the assembly of the translocators [81]. These data suggest that the tip proteins are exported after the needle is assembled but before the later substrates. In Shigella, the translocator protein IpaB has also been identified at the needle tip prior to membrane contact and without IpaC recruitment [81-83]. Although the lack of detection of IpaC may be due to technical limitations, these data suggest that there is a stepwise secretion of the proteins that sit at the tip of the needle. Whether there are distinct triggers for the secretion of each of these components remains uncertain. However, it is clear that the exact conditions under which these experiments are conducted are critical in determining which components are identified. For this reason, there is some ambiguity about whether the translocator proteins are a distinct secretion category from both the tip proteins and the late effectors.

The transition from blockage to activation of effector secretion can be considered the second switch of the T3SS (Fig. 1c, d). A family of proteins, of which MxiC is the Shigella homologue, has been identified that act as regulators at this stage. Functional knockouts of members of this family have no effect on needle formation or stability, but do result in enhanced secretion of effector proteins $[17-19,84,85]$. It has been proposed that these proteins play an active role in repressing the secretion of effectors and that they may function by interacting with the T3SS apparatus in a manner that blocks secretion $[84,86]$. In support of this hypothesis, Botteaux et al. recently identified an interaction between MxiC and the ATPase, Spa47 [17].

The Yersinia homologue of MxiC differs from that of other species in that it exists as two separate polypeptide chains: YopN and TyeA [87]. However, the structure of the YopN-TyeA complex is very similar to that of the S. flexneri homologue MxiC (Fig. 3a) [88, 89]. The structures reveal that these proteins are rod-shaped with a highly disordered $\mathrm{N}$-terminus that possesses the secretion signal and chaperone-binding region [90]. The rod shape provides these proteins with a large surface area potentially allowing for simultaneous interactions with several partner proteins. Despite their similar fold, consisting of multiple bundles of $\alpha$-helices, these proteins possess almost no sequence conservation on their surfaces, suggesting that the sequences of the proteins they interact with are also not highly conserved. Interestingly, the overall shape of these two structures is quite different due to twisting of some domains and the kinking of a long, central helix (Fig. 3a). Specifically, YopN-TyeA has a more curved shape, whereas $\mathrm{MxiC}$ is quite straight. The conditions in which the crystals of these proteins grew had very different $\mathrm{pH}$
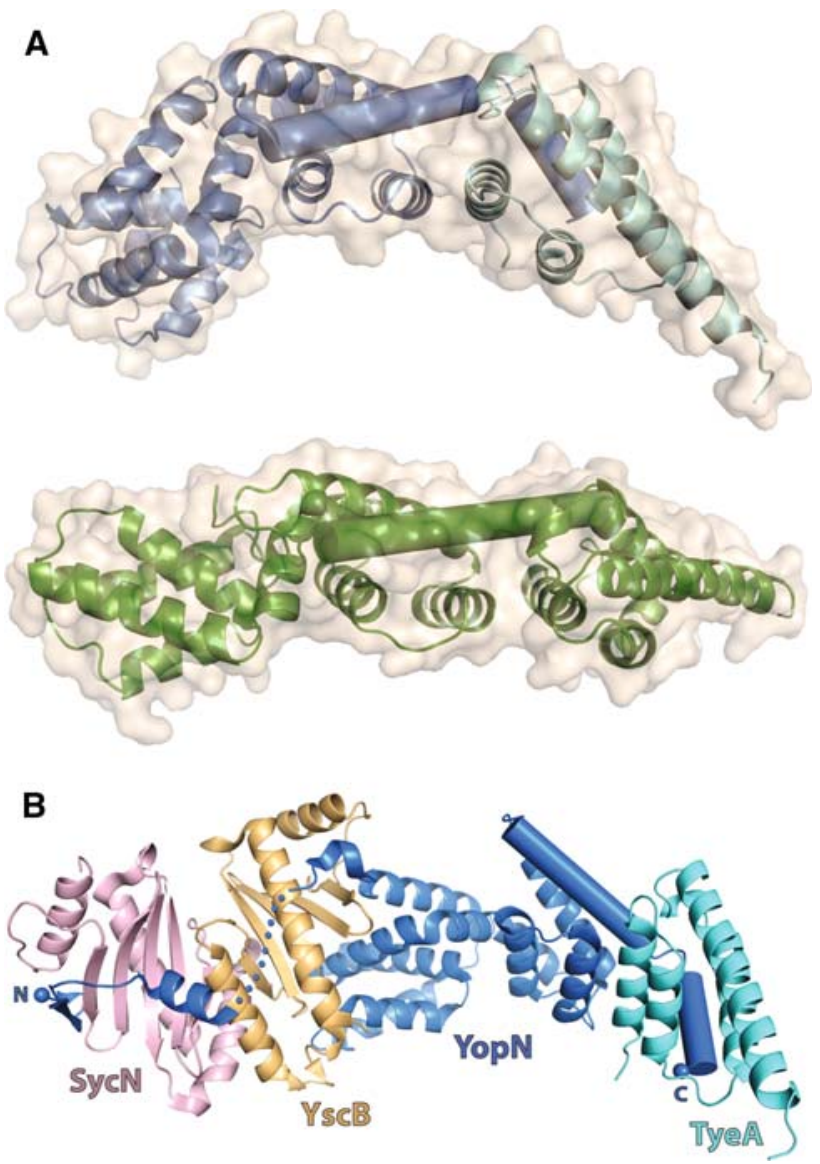

Fig. 3 Structures of YopN complexes and MxiC. a Surface representations (wheat) and ribbon diagrams of: YopN (blue) in complex with TyeA (cyan) and MxiC (green). The central helix discussed in the text is displayed as a cylinder. b Ribbon diagram of the complex formed by YopN (blue), TyeA (cyan) and the chaperones SycN (pink) and $\mathrm{YscB}$ (yellow). The $\mathrm{N}$ - and C-terminal residues of YopN are highlighted (balls), and an unstructured region of YopN is displayed as a dashed line

values: MxiC crystals were grown at $\mathrm{pH}$ 6.5-7.5, whereas YopN-TyeA crystals grew at $\mathrm{pH} 10.5$. Whether the differences in these structures provide a glimpse of a functionally important, potentially $\mathrm{pH}$-dependent, conformational change or whether they are artefacts of crystallisation will require further study.

The structure of YopN in complex with its heterodimeric chaperone, SycN-YscB, has also been determined (Fig. 3b) [89]. Although homologues have been identified for most other chaperones within the T3SS, the homologues of $\mathrm{SycN}$ and $\mathrm{YscB}$ have not yet been clearly identified in other species. The binding faces for TyeA and the chaperone complex lie at opposite ends of YopN and are structurally independent. This observation suggests that the different functions this family of proteins possess may be structurally separated. Indeed, recent work with the E. coli homologue, SepL, has demonstrated that its 
different functions, including membrane localisation, translocator export and effector secretion regulation, can be separated [91].

The effects of knockouts in this family on tip and translocator secretion seem to differ between species. In E. coli and Salmonella, knockout of SepL or InvE, respectively, reduce or abolish the secretion of the tip protein and translocators $[19,20,84,92]$. This phenotype is similar to that observed for the N263A mutant of $\mathrm{YscU}$, namely the absence of tip and translocator secretion while retaining the ability to secrete effector proteins. However, an understanding of whether there is some co-ordination between the first and second switches in these species will require further study.

The secretion of tip and translocator proteins is not affected in Shigella and Yersinia strains knocked out for MxiC and YopN, respectively [17, 65, 93]. However, these strains are impaired in cell invasion and do not efficiently translocate effectors. YopN is secreted by the T3SS, and it has been suggested that TyeA suppresses the secretion of YopN prior to host-cell contact. The dissociation of YopN and TyeA has been proposed as a mechanism for the regulation of secretion, but clearly this cannot be a conserved mechanism in those species where the homologue is a single polypeptide chain [94, 95]. However, recently it has been shown that in Shigella, MxiC is secreted and that its secretion is required for its function [17]. In other species, secretion of this component has not been seen.

In E. coli, it has been suggested that SepL and its binding partner SepD control a switch from translocator to effector secretion by sensing certain environmental signals such as low calcium [84]. Similarly, in Yersinia, changes in the environmental calcium concentration are thought to relieve the TyeA-mediated blockage, triggering the secretion of YopN and activating secretion [96-98]. This response to low calcium levels is thought to involve both the YopN-TyeA complex and a pathway involving the negative regulator, LcrG, and its interaction with the tip protein, LcrV [99, 100]. Recently, LcrG has also been implicated in the negative regulation of transcription of T3SS genes [101]. The indirect role played by LcrG in transcriptional regulation is similar to that seen by Botteaux et al. in a MxiC mutant that showed increased expression of effector genes due to the increased secretion of the anti-activator OspD1 [17, 102]. The secretion of regulatory proteins is a convenient mechanism to control their levels in the cell and provides one means of co-ordinating secretion and switching. In flagella, this has been well studied for the regulatory protein FlgM (reviewed in [27]). In addition, there is evidence that posttranscriptional cleavage of transcripts plays a role in the regulation of protein production [103]. The mechanisms of this regulation are only beginning to be understood.
The data currently available for the regulation of type III secretion do not support any single model for each step. It is likely that there are subtle differences between species due to varying numbers and types of proteins present in the virulence repertoires of different species. Furthermore, the final trigger for effector secretion is likely to be unique to each species due to their different host specificities and local environments at infection.

Acknowledgments JED, PA and SJ are funded by a Wellcome Trust Programme Grant (WT083599MA) to SML.

Open Access This article is distributed under the terms of the Creative Commons Attribution Noncommercial License which permits any noncommercial use, distribution, and reproduction in any medium, provided the original author(s) and source are credited.

\section{References}

1. Moraes TF, Spreter T, Strynadka NC (2008) Piecing together the type III injectisome of bacterial pathogens. Curr Opin Struct Biol 18:258-266

2. Yip CK, Strynadka NC (2006) New structural insights into the bacterial type III secretion system. Trends Biochem Sci 31:223230

3. Sukhan A, Kubori T, Wilson J, Galan JE (2001) Genetic analysis of assembly of the Salmonella enterica serovar Typhimurium type III secretion-associated needle complex. J Bacteriol 183:1159-1167

4. He SY, Nomura K, Whittam TS (2004) Type III protein secretion mechanism in mammalian and plant pathogens. Biochim Biophys Acta 1694:181-206

5. Blocker AJ, Deane JE, Veenendaal AK, Roversi P, Hodgkinson JL, Johnson S, Lea SM (2008) What's the point of the type III secretion system needle? Proc Natl Acad Sci USA 105:65076513

6. Wang Y, Zhang L, Picking WL, Picking WD, De Guzman RN (2008) Structural dissection of the extracellular moieties of the type III secretion apparatus. Mol Biosyst 4:1176-1180

7. Li CM, Brown I, Mansfield J, Stevens C, Boureau T, Romantschuk M, Taira S (2002) The Hrp pilus of Pseudomonas syringae elongates from its tip and acts as a conduit for translocation of the effector protein HrpZ. EMBO J 21:1909-1915

8. Jin Q, He SY (2001) Role of the Hrp pilus in type III protein secretion in Pseudomonas syringae. Science 294:2556-2558

9. Mueller CA, Broz P, Cornelis GR (2008) The type III secretion system tip complex and translocon. Mol Microbiol 68:10851095

10. Journet L, Agrain C, Broz P, Cornelis GR (2003) The needle length of bacterial injectisomes is determined by a molecular ruler. Science 302:1757-1760

11. Kubori T, Sukhan A, Aizawa SI, Galan JE (2000) Molecular characterization and assembly of the needle complex of the Salmonella typhimurium type III protein secretion system. Proc Natl Acad Sci USA 97:10225-10230

12. Tamano K, Katayama E, Toyotome T, Sasakawa C (2002) Shigella Spa32 is an essential secretory protein for functional type III secretion machinery and uniformity of its needle length. J Bacteriol 184:1244-1252

13. Magdalena J, Hachani A, Chamekh M, Jouihri N, Gounon P, Blocker A, Allaoui A (2002) Spa32 regulates a switch in 
substrate specificity of the type III secretion of Shigella flexneri from needle components to Ipa proteins. J Bacteriol 184:34333441

14. Botteaux A, Sani M, Kayath CA, Boekema EJ, Allaoui A (2008) Spa32 interaction with the inner-membrane Spa40 component of the type III secretion system of Shigella flexneri is required for the control of the needle length by a molecular tape measure mechanism. Mol Microbiol 70:1515-1528

15. Edqvist PJ, Olsson J, Lavander M, Sundberg L, Forsberg A, Wolf-Watz H, Lloyd SA (2003) YscP and YscU regulate substrate specificity of the Yersinia type III secretion system. J Bacteriol 185:2259-2266

16. Menard R, Sansonetti P, Parsot C (1994) The secretion of the Shigella flexneri Ipa invasins is activated by epithelial cells and controlled by IpaB and IpaD. EMBO J 13:5293-5302

17. Botteaux A, Sory MP, Biskri L, Parsot C, Allaoui A (2009) MxiC is secreted by and controls the substrate specificity of the Shigella flexneri type III secretion apparatus. Mol Microbiol 71:449-460

18. Forsberg A, Viitanen AM, Skurnik M, Wolf-Watz H (1991) The surface-located YopN protein is involved in calcium signal transduction in Yersinia pseudotuberculosis. Mol Microbiol 5:977-986

19. Kubori T, Galan JE (2002) Salmonella type III secretion-associated protein InvE controls translocation of effector proteins into host cells. J Bacteriol 184:4699-4708

20. O'Connell CB, Creasey EA, Knutton S, Elliott S, Crowther LJ, Luo W, Albert MJ, Kaper JB, Frankel G, Donnenberg MS (2004) SepL, a protein required for enteropathogenic Escherichia coli type III translocation, interacts with secretion component SepD. Mol Microbiol 52:1613-1625

21. Blocker A, Gounon P, Larquet E, Niebuhr K, Cabiaux V, Parsot C, Sansonetti P (1999) The tripartite type III secretion of Shigella flexneri inserts IpaB and IpaC into host membranes. J Cell Biol 147:683-693

22. Hakansson S, Schesser K, Persson C, Galyov EE, Rosqvist R, Homble F, Wolf-Watz H (1996) The YopB protein of Yersinia pseudotuberculosis is essential for the translocation of Yop effector proteins across the target cell plasma membrane and displays a contact-dependent membrane disrupting activity. EMBO J 15:5812-5823

23. Brutinel ED, Yahr TL (2008) Control of gene expression by type III secretory activity. Curr Opin Microbiol 11:128-133

24. Aldridge P, Hughes KT (2002) Regulation of flagellar assembly. Curr Opin Microbiol 5:160-165

25. Minamino T, Imada K, Namba K (2008) Mechanisms of type III protein export for bacterial flagellar assembly. Mol Biosyst 4:1105-1115

26. Minamino T, Imada K, Namba K (2008) Molecular motors of the bacterial flagella. Curr Opin Struct Biol 18:693-701

27. Chevance FF, Hughes KT (2008) Coordinating assembly of a bacterial macromolecular machine. Nat Rev Microbiol 6:455465

28. Marlovits TC, Kubori T, Sukhan A, Thomas DR, Galan JE, Unger VM (2004) Structural insights into the assembly of the type III secretion needle complex. Science 306:1040-1042

29. Hodgkinson JL, Horsley A, Stabat D, Simon M, Johnson S, da Fonseca PC, Morris EP, Wall JS, Lea SM, Blocker AJ (2009) Three-dimensional reconstruction of the Shigella T3SS transmembrane regions reveals 12 -fold symmetry and novel features throughout. Nat Struct Mol Biol 16:477-485

30. Saijo-Hamano Y, Minamino T, Macnab RM, Namba K (2004) Structural and functional analysis of the $\mathrm{C}$-terminal cytoplasmic domain of FlhA, an integral membrane component of the type III flagellar protein export apparatus in Salmonella. J Mol Biol 343:457-466
31. McMurry JL, Van Arnam JS, Kihara M, Macnab RM (2004) Analysis of the cytoplasmic domains of Salmonella FlhA and interactions with components of the flagellar export machinery. J Bacteriol 186:7586-7592

32. Minamino T, Macnab RM (2000) Domain structure of Salmonella FlhB, a flagellar export component responsible for substrate specificity switching. J Bacteriol 182:4906-4914

33. Parsot C, Hamiaux C, Page AL (2003) The various and varying roles of specific chaperones in type III secretion systems. Curr Opin Microbiol 6:7-14

34. Page AL, Parsot C (2002) Chaperones of the type III secretion pathway: jacks of all trades. Mol Microbiol 46:1-11

35. Wilharm G, Dittmann S, Schmid A, Heesemann J (2007) On the role of specific chaperones, the specific ATPase, and the proton motive force in type III secretion. Int J Med Microbiol 297:27-36

36. Ghosh P (2004) Process of protein transport by the type III secretion system. Microbiol Mol Biol Rev 68:771-795

37. Ramamurthi KS, Schneewind O (2002) Yersinia enterocolitica type III secretion: mutational analysis of the yopQ secretion signal. J Bacteriol 184:3321-3328

38. Anderson DM, Schneewind O (1997) A mRNA signal for the type III secretion of Yop proteins by Yersinia enterocolitica. Science 278:1140-1143

39. Subtil A, Parsot C, Dautry-Varsat A (2001) Secretion of predicted Inc proteins of Chlamydia pneumoniae by a heterologous type III machinery. Mol Microbiol 39:792-800

40. Karavolos MH, Roe AJ, Wilson M, Henderson J, Lee JJ, Gally DL, Khan CM (2005) Type III secretion of the Salmonella effector protein SopE is mediated via an N-terminal amino acid signal and not an mRNA sequence. J Bacteriol 187:1559-1567

41. Crawford JA, Kaper JB (2002) The N-terminus of enteropathogenic Escherichia coli (EPEC) Tir mediates transport across bacterial and eukaryotic cell membranes. Mol Microbiol 46:855-868

42. Lloyd SA, Norman M, Rosqvist R, Wolf-Watz H (2001) Yersinia YopE is targeted for type III secretion by N-terminal, not mRNA, signals. Mol Microbiol 39:520-531

43. Samudrala R, Heffron F, McDermott JE (2009) Accurate prediction of secreted substrates and identification of a conserved putative secretion signal for type III secretion systems. PLoS Pathog 5:e1000375

44. Arnold R, Brandmaier S, Kleine F, Tischler P, Heinz E, Behrens S, Niinikoski A, Mewes HW, Horn M, Rattei T (2009) Sequence-based prediction of type III secreted proteins. PLoS Pathog 5:e1000376

45. Lower M, Schneider G (2009) Prediction of type III secretion signals in genomes of Gram-negative bacteria. PLoS One 4:e5917

46. Morello JE, Collmer A (2009) Pseudomonas syringae HrpP is a type III secretion substrate specificity switch domain protein that is translocated into plant cells but functions atypically for a substrate-switching protein. J Bacteriol 191:3120-3131

47. Agrain C, Sorg I, Paroz C, Cornelis GR (2005) Secretion of YscP from Yersinia enterocolitica is essential to control the length of the injectisome needle but not to change the type III secretion substrate specificity. Mol Microbiol 57:1415-1427

48. Mota LJ, Journet L, Sorg I, Agrain C, Cornelis GR (2005) Bacterial injectisomes: needle length does matter. Science 307:1278

49. West NP, Sansonetti P, Mounier J, Exley RM, Parsot C, Guadagnini S, Prevost MC, Prochnicka-Chalufour A, Delepierre M, Tanguy M, Tang CM (2005) Optimization of virulence functions through glucosylation of Shigella LPS. Science 307:1313-1317

50. Kimbrough TG, Miller SI (2000) Contribution of Salmonella typhimurium type III secretion components to needle complex formation. Proc Natl Acad Sci USA 97:11008-11013 
51. Collazo CM, Galan JE (1996) Requirement for exported proteins in secretion through the invasion-associated type III system of Salmonella typhimurium. Infect Immun 64:3524-3531

52. Tamano K, Aizawa S, Katayama E, Nonaka T, Imajoh-Ohmi S, Kuwae A, Nagai S, Sasakawa C (2000) Supramolecular structure of the Shigella type III secretion machinery: the needle part is changeable in length and essential for delivery of effectors. EMBO J 19:3876-3887

53. Payne PL, Straley SC (1999) YscP of Yersinia pestis is a secreted component of the Yop secretion system. J Bacteriol $181: 2852-2862$

54. Stainier I, Bleves S, Josenhans C, Karmani L, Kerbourch C, Lambermont I, Totemeyer S, Boyd A, Cornelis GR (2000) YscP, a Yersinia protein required for Yop secretion that is surface exposed, and released in low $\mathrm{Ca}^{2+}$. Mol Microbiol 37:1005-1018

55. Cornelis GR, Agrain C, Sorg I (2006) Length control of extended protein structures in bacteria and bacteriophages. Curr Opin Microbiol 9:201-206

56. Thomas NA, Finlay BB (2004) Pathogens: bacterial needles ruled to length and specificity. Curr Biol 14:R192-R194

57. Waters RC, O’Toole PW, Ryan KA (2007) The FliK protein and flagellar hook-length control. Protein Sci 16:769-780

58. Ferris HU, Minamino T (2006) Flipping the switch: bringing order to flagellar assembly. Trends Microbiol 14:519-526

59. Wagner S, Sorg I, Degiacomi M, Journet L, Dal Peraro M, Cornelis GR (2009) The helical content of the YscP molecular ruler determines the length of the Yersinia injectisome. Mol Microbiol 71:692-701

60. Moriya N, Minamino T, Hughes KT, Macnab RM, Namba K (2006) The type III flagellar export specificity switch is dependent on FliK ruler and a molecular clock. J Mol Biol 359:466-477

61. Cordes FS, Komoriya K, Larquet E, Yang S, Egelman EH, Blocker A, Lea SM (2003) Helical structure of the needle of the type III secretion system of Shigella flexneri. J Biol Chem 278:17103-17107

62. Deane JE, Roversi P, Cordes FS, Johnson S, Kenjale R, Daniell S, Booy F, Picking WD, Picking WL, Blocker AJ, Lea SM (2006) Molecular model of a type III secretion system needle: implications for host-cell sensing. Proc Natl Acad Sci USA 103:12529-12533

63. Agrain C, Callebaut I, Journet L, Sorg I, Paroz C, Mota LJ, Cornelis GR (2005) Characterization of a Type III secretion substrate specificity switch (T3S4) domain in YscP from Yersinia enterocolitica. Mol Microbiol 56:54-67

64. Zarivach R, Deng W, Vuckovic M, Felise HB, Nguyen HV, Miller SI, Finlay BB, Strynadka NC (2008) Structural analysis of the essential self-cleaving type III secretion proteins EscU and SpaS. Nature 453:124-127

65. Sorg I, Wagner S, Amstutz M, Muller SA, Broz P, Lussi Y, Engel A, Cornelis GR (2007) YscU recognizes translocators as export substrates of the Yersinia injectisome. EMBO J 26:30153024

66. Deane JE, Graham SC, Mitchell EP, Flot D, Johnson S, Lea SM (2008) Crystal structure of Spa40, the specificity switch for the Shigella flexneri type III secretion system. Mol Microbiol 69:267-276

67. Wiesand U, Sorg I, Amstutz M, Wagner S, van den Heuvel J, Luhrs T, Cornelis GR, Heinz DW (2009) Structure of the type III secretion recognition protein YscU from Yersinia enterocolitica. J Mol Biol 385:854-866

68. Lountos GT, Austin BP, Nallamsetty S, Waugh DS (2009) Atomic resolution structure of the cytoplasmic domain of Yersinia pestis YscU, a regulatory switch involved in type III secretion. Protein Sci 18:467-474
69. Fraser GM, Hirano T, Ferris HU, Devgan LL, Kihara M, Macnab RM (2003) Substrate specificity of type III flagellar protein export in Salmonella is controlled by subdomain interactions in FlhB. Mol Microbiol 48:1043-1057

70. Kutsukake K, Minamino T, Yokoseki T (1994) Isolation and characterization of FliK-independent flagellation mutants from Salmonella typhimurium. J Bacteriol 176:7625-7629

71. Williams AW, Yamaguchi S, Togashi F, Aizawa SI, Kawagishi I, Macnab RM (1996) Mutations in fliK and flhB affecting flagellar hook and filament assembly in Salmonella typhimurium. J Bacteriol 178:2960-2970

72. Riordan KE, Schneewind O (2008) YscU cleavage and the assembly of Yersinia type III secretion machine complexes. Mol Microbiol 68:1485-1501

73. Riordan KE, Sorg JA, Berube BJ, Schneewind O (2008) Impassable YscP substrates and their impact on the Yersinia enterocolitica type III secretion pathway. J Bacteriol 190:62046216

74. Marlovits TC, Kubori T, Lara-Tejero M, Thomas D, Unger VM, Galan JE (2006) Assembly of the inner rod determines needle length in the type III secretion injectisome. Nature 441:637-640

75. Kubori T, Matsushima Y, Nakamura D, Uralil J, Lara-Tejero M, Sukhan A, Galan JE, Aizawa SI (1998) Supramolecular structure of the Salmonella typhimurium type III protein secretion system. Science 280:602-605

76. Wood SE, Jin J, Lloyd SA (2008) YscP and YscU switch the substrate specificity of the Yersinia type III secretion system by regulating export of the inner rod protein YscI. J Bacteriol 190:4252-4262

77. Mueller CA, Broz P, Muller SA, Ringler P, Erne-Brand F, Sorg I, Kuhn M, Engel A, Cornelis GR (2005) The V-antigen of Yersinia forms a distinct structure at the tip of injectisome needles. Science 310:674-676

78. Espina M, Olive AJ, Kenjale R, Moore DS, Ausar SF, Kaminski RW, Oaks EV, Middaugh CR, Picking WD, Picking WL (2006) IpaD localizes to the tip of the type III secretion system needle of Shigella flexneri. Infect Immun 74:4391-4400

79. Sani M, Botteaux A, Parsot C, Sansonetti P, Boekema EJ, Allaoui A (2007) IpaD is localized at the tip of the Shigella flexneri type III secretion apparatus. Biochim Biophys Acta 1770:307-311

80. Zhang L, Wang Y, Olive AJ, Smith ND, Picking WD, De Guzman RN, Picking WL (2007) Identification of the MxiH needle protein residues responsible for anchoring invasion plasmid antigen D to the type III secretion needle tip. J Biol Chem 282:32144-32151

81. Veenendaal AK, Hodgkinson JL, Schwarzer L, Stabat D, Zenk SF, Blocker AJ (2007) The type III secretion system needle tip complex mediates host cell sensing and translocon insertion. Mol Microbiol 63:1719-1730

82. Epler CR, Dickenson NE, Olive AJ, Picking WL, Picking WD (2009) Liposomes recruit IpaC to the Shigella flexneri type III secretion apparatus needle as a final step in secretion induction. Infect Immun 77:2754-2761

83. Olive AJ, Kenjale R, Espina M, Moore DS, Picking WL, Picking WD (2007) Bile salts stimulate recruitment of IpaB to the Shigella flexneri surface, where it colocalizes with IpaD at the tip of the type III secretion needle. Infect Immun 75:26262629

84. Deng W, Li Y, Hardwidge PR, Frey EA, Pfuetzner RA, Lee S, Gruenheid S, Strynakda NC, Puente JL, Finlay BB (2005) Regulation of type III secretion hierarchy of translocators and effectors in attaching and effacing bacterial pathogens. Infect Immun 73:2135-2146

85. Boland A, Sory MP, Iriarte M, Kerbourch C, Wattiau P, Cornelis GR (1996) Status of YopM and YopN in the Yersinia 
Yop virulon: YopM of Y.enterocolitica is internalized inside the cytosol of PU5-1.8 macrophages by the YopB, D, N delivery apparatus. EMBO J 15:5191-5201

86. Joseph SS, Plano GV (2007) Identification of TyeA residues required to interact with YopN and to regulate Yop secretion. Adv Exp Med Biol 603:235-245

87. Pallen MJ, Beatson SA, Bailey CM (2005) Bioinformatics analysis of the locus for enterocyte effacement provides novel insights into type-III secretion. BMC Microbiol 5:9

88. Deane JE, Roversi P, King C, Johnson S, Lea SM (2008) Structures of the Shigella flexneri type 3 secretion system protein MxiC reveal conformational variability amongst homologues. J Mol Biol 377:985-992

89. Schubot FD, Jackson MW, Penrose KJ, Cherry S, Tropea JE, Plano GV, Waugh DS (2005) Three-dimensional structure of a macromolecular assembly that regulates type III secretion in Yersinia pestis. J Mol Biol 346:1147-1161

90. Goss JW, Sorg JA, Ramamurthi KS, Ton-That H, Schneewind O (2004) The secretion signal of YopN, a regulatory protein of the Yersinia enterocolitica type III secretion pathway. J Bacteriol 186:6320-6324

91. Wang D, Roe AJ, McAteer S, Shipston MJ, Gally DL (2008) Hierarchal type III secretion of translocators and effectors from Escherichia coli $\mathrm{O} 157: \mathrm{H} 7$ requires the carboxy terminus of SepL that binds to Tir. Mol Microbiol 69:1499-1512

92. Kresse AU, Beltrametti F, Muller A, Ebel F, Guzman CA (2000) Characterization of SepL of enterohemorrhagic Escherichia coli. J Bacteriol 182:6490-6498

93. Marenne MN, Journet L, Mota LJ, Cornelis GR (2003) Genetic analysis of the formation of the Ysc-Yop translocation pore in macrophages by Yersinia enterocolitica: role of $\mathrm{LcrV}, \mathrm{YscF}$ and YopN. Microb Pathog 35:243-258

94. Ferracci F, Schubot FD, Waugh DS, Plano GV (2005) Selection and characterization of Yersinia pestis YopN mutants that constitutively block Yop secretion. Mol Microbiol 57:970-987
95. Ferracci F, Day JB, Ezelle HJ, Plano GV (2004) Expression of a functional secreted YopN-TyeA hybrid protein in Yersinia pestis is the result of a +1 translational frameshift event. J Bacteriol 186:5160-5166

96. Sundberg L, Forsberg A (2003) TyeA of Yersinia pseudotuberculosis is involved in regulation of Yop expression and is required for polarized translocation of Yop effectors. Cell Microbiol 5:187-202

97. Day JB, Ferracci F, Plano GV (2003) Translocation of YopE and YopN into eukaryotic cells by Yersinia pestis yopN, tyeA, sycN, yscB and lcrG deletion mutants measured using a phosphorylatable peptide tag and phosphospecific antibodies. Mol Microbiol 47:807-823

98. Cheng LW, Kay O, Schneewind O (2001) Regulated secretion of YopN by the type III machinery of Yersinia enterocolitica. J Bacteriol 183:5293-5301

99. Matson JS, Nilles ML (2001) LcrG-LcrV interaction is required for control of Yops secretion in Yersinia pestis. J Bacteriol 183:5082-5091

100. DeBord KL, Lee VT, Schneewind O (2001) Roles of LcrG and LcrV during type III targeting of effector Yops by Yersinia enterocolitica. J Bacteriol 183:4588-4598

101. Du Z, Tan Y, Yang H, Qiu J, Qin L, Wang T, Liu H, Bi Y, Song Y, Guo Z, Han Y, Zhou D, Wang X, Yang R (2009) Gene expression profiling of Yersinia pestis with deletion of lcrG, a known negative regulator for Yop secretion of type III secretion system. Int J Med Microbiol 299:355-366

102. Parsot C, Ageron E, Penno C, Mavris M, Jamoussi K, d'Hauteville H, Sansonetti P, Demers B (2005) A secreted antiactivator, OspD1, and its chaperone, Spa15, are involved in the control of transcription by the type III secretion apparatus activity in Shigella flexneri. Mol Microbiol 56:1627-1635

103. Lodato PB, Kaper JB (2009) Post-transcriptional processing of the LEE4 operon in enterohaemorrhagic Escherichia coli. Mol Microbiol 71:273-290 